\title{
KEMAMPUAN MENULIS PUISI SISWA KELAS VIII SEMESTER GENAP SMP PERINTIS 2 BANDAR LAMPUNG TAHUN PELAJARAN 2019/2020
}

\author{
Salamah \\ Universitas Muhammadiyah Lampung \\ salamsalamah871@gmail.com
}

\begin{abstract}
Abstrak: Permasalahan yang dapat dijadikan dalam penelitian ini disebabkan adanya kelemahan siswa dalam menulis puisi. Hal-hal yang dianalisis meliputi 1) rima, 2) imajinasi, 3) diksi, 4) kata konkret, 5) majas. Penelitian ini dilakukan dengan tujuan untuk mendeskripsikan kemampuan siswa kelas VIII semester genap SMP Perintis 2 Bandar Lampung Tahun Pelajaran 2019/2020, dalam menulis puisi berdasarkan tema yang telah ditentukan dan mengetahui berbagai faktor yang dapat menyebabkan kesulitan siswa dalam menulis puisi.
\end{abstract}

Metode penelitian yang digunakan dalam penelitian ini yakni deskriptif kualitatif. Subjek penelitian ini adalah semua kelas VIII semester genap SMP Perintis 2 Bandar Lampung Tahun Pelajaran 2019/2020, berjumlah 354 siswa, terbagi ke dalam 8 kelas dengan subjek inti sebanyak 35 orang yang diambil dengan teknik random sampling. Teknik pengumpulan data penelitian menggunakan teknik tes unjuk kerja yakni menugaskan siswa untuk menulis puisi berdasarkan tema yang telah ditentukan. Teknik analisis data menggunakan deskriptif kualitatif, yakni dengan menganalisis ketepatan siswa menulis puisi berdasarkan aspek yang dinilai.

Hasil penelitian menunjukkan bahwa kemampuan siswa kelas VIII semester genap SMP Perintis 2 Bandar Lampung Tahun Pelajaran 2019/2020, dalam menulis puisi belum sepenuhnya dapat dikatakan berhasil. Hal ini disebabkan karena masih ada unsur-unsur yang kurang tepat dalam menulis puisi. Kesalahan atau kelemahan siswa yang sering ditemukan yaitu pada aspek rima, diksi dan kata konkret. Umumnya, setiap siswa dalam menulis puisi kurang tepat atau tidak menggunakan aspek tersebut. Puisi yang ditulis siswa terkesan seperti prosa, kata-kata yang datar dan biasa, sehingga kurang memberikan nilai keindahan. Tidak adanya kesamaan rima pada tiap baitnya juga merupakan salah satu kelemahan siswa, rima cenderung tidak mengikuti pola dengan baik, sehingga rima pada puisi tidak jelas dan menimbulkan ketidakselarasan. Kata-kata yang datar juga mempengaruhi aspek diksi karena dapat membuat puisi kurang menarik sehingga tidak terkesan pada nilai-nilai keindahan sebuah karya sastra.

Kata kunci : rima, imajinasi, diksi, kata konkret, majas.

Abstract: The problem that could be used in this study was due to the weakness of students in writing poetry. The things analyzed include 1) rhyme, 2) imagination, 3) dictation, 4) concrete words, 5) Figure of speech. This research was conducted with the aim of describing the ability of grade VIII students of the even semester of Perintis 2 Bandar Lampung Junior High School, Academic year 2019/2020, in writing poetry based on the specified theme and knowing various factors that could cause students to write poetry. 
The research method used in this study was descriptive qualitative. The subjects of this study were all VIII grade in the even semester of Perintis 2 Bandar Lampung Junior High School, Academic year 2019/2020, amounted to 354 students, divided into 8 classes with core subjects as many as 35 people taken with random sampling techniques. The technique of collecting research data using work show techniques was to assign students to write poems based on predetermined themes. Data analysis techniques used qualitative descriptive, namely by analyzing the accuracy of students to write poetry based on assessed aspects.

The results showed that the ability of grade VIII students in the even semester of Perintis 2 Bandar Lampung Junior High School, Academic year 2019/2020, in writing poetry could not fully be said to be successful. This was because there were still less appropriate elements in writing poetry. Errors or weaknesses of students who were often found were aspects of rhyme, dictation and concrete words. Generally, every student in writing poetry was not appropriate or did not use the aspect. Poetry written students seem like prose, words that were flat and ordinary, so they did not provide the value of beauty. The lack of confusion in each temple was also one of the weaknesses of students, rhyme tended to not follow the pattern well, so that rhyme in poetry was unclear and caused inconsistencies. Flat words also affected the aspects of the diction because they could make poems less attractive so they were not impressed by the values of the beauty of a literary work.

Keywords: rhyme, imagination, diction, concrete words, figure of speech.

\section{PENDAHULUAN}

Menulis adalah kegiatan untuk mengapresiasikan sebuah gagasan yang masih dalam bentuk anganangan untuk dituangkan dalam media tulis. Pada hakikatnya bahwa menulis adalah bentuk penyampaian informasi berupa bacaan secara utuh yang telah disampaikan melalui gagasan untuk dapat dipahami oleh para pembaca. Oleh karena itu, Menulis berarti melakukan kegiatan menyusun gagasan secara sistematis. Di mana kegiatan menulis merupakan suatu proses bentuk penyampaian yang diungkapkan melalui media tulis untuk diketahui oleh khalayak secara umum dan memiliki maksud dan tujuan tertentu.

Menulis puisi merupakan proses terjadinya pengimajinasian seseorang yang sedang berlangsung pada seketika. Kemampuan menulis puisi banyak manfaat yang diperoleh sebab, menulis puisi siswa dapat menuangkan ide secara leluasa serta dapat mempertajam pengamatan dan meningkatkan kemampuan berbahasa dan terjadi proses kreatif serta menghasilkan tulisan yang memiliki nilai keindahan dalam penggunaan diksi yang digunakan. Selain itu, kemampuan menulis puisi dapat membantu siswa berpikir kritis, kreatif, memperdalam daya tangkap, dan menyusun urutan pengalaman. Kemampuan menulis puisi yang perlu dimiliki oleh siswa, harus disertai dengan pemahaman terhadap berbagai hal yang mempengaruhi keberhasilan menulis puisi.

Hal-hal tersebut di antaranya dapat memahami konsep puisi, struktur penulisan puisi, dan teknik menulis yang baik. Selain memahami hal-hal tersebut, siswa harus diarahkan untuk berlatih 
menulis puisi dan menerapkannya. Dengan demikian, bukan hanya pemahaman terhadap konsep belaka, melainkan dapat menghasilkan puisi sebagai kreativitasnya. Kreativitas siswa dalam menulis puisi dapat memberikan sebuah motivator yang sangat tinggi, karena seorang siswa dituntut untuk melatih kemampuannya dalam berimajinasi. Oleh sebab itu, telah diamanahkan dalam kurikulum KTSP tahun 2006, yakni dalam silabus bahasa Indonesia. Hal tersebut jelas terdapat dalam standar kompetensi (SK) dan kompetensi dasar (KD). Standar kompetensinya yakni menuangkan eloknya alam semesta dan proses kegiatan dalam berimajinasi melalui proses pengamatan sehingga dapat diapresiasikan dengan aktivitas menulis. sedangkan kompetensi dasarnya yakni proses aktivitas untuk menuangkan gagasan dari hasil pengamatan melalui panca indra dan sebuah pengalaman hidup seseorang. Hal-hal yang harus dipelajari oleh siswa agar mencapai tujuan dan harapan dalam SK dan KD tersebut yakni menguasai konsep puisi, unsur-unsur puisi, langkah menulisnya yang baik dan melakukan latihan yang terusmenerus, bukan hanya di sekolah melainkan di rumah juga. Hal tersebut akan menambah pengetahuan peserta didik dalam memahami aspek ketrampilan berbahasa. Tujuan dan harapan yang ada dalam SK dan KD tersebut, menurut informasi bahwa materi menulis puisi telah disampaikan kepada siswa, bukan hanya konsep-konsepnya melainkan praktiknya juga. Akan tetapi, kenyataan menunjukkan bahwa harapan yang ada dalam SK dan KD belum sepenuhnya tercapai. Masih terdapat beberapa siswa yang belum dapat menulis puisi dengan baik. Puisi yang seharusnya ditulis dengan memperhatikan unsur-unsur puisi, baik unsur dalam maupun unsur luarnya, ternyata terdapat sebagian yang belum memenuhi kriteria tersebut.

Berdasarkan saat penelitian dilakukan, beberapa siswa kelas VIII Semester genap SMP Perintis 2 Bandar Lampung Tahun Pelajaran 2019/2020 diberikan tugas berupa latihan untuk menulis puisi dengan pemahaman siswa sendiri. Ternyata, puisi yang ditulis, setelah dilihat dan ditinjau dari syarat puisi yang baik, secara umum belum memenuhi unsur-unsur penulisan puisi. Puisi yang dibuat, dilihat dari segi tema, masih cenderung tidak mewakili gagasan yang disampaikan. Kata-kata yang dipakai terkesan kurang memahami situasi dan suasana yang digambarkan dalam puisi tersebut. hal ini berdampak pada tidak adanya efek dari puisi kepada pembaca. Bahkan, dilihat dari gaya penuturannya atau gaya bahasa yang harusnya menghiasi puisi siswa, justru sama sekali tidak tampak. Selain itu, daya imajinasi yang ditimbulkan pun masih kurang ketika dibaca. Artinya, puisi yang dibuat siswa ketika dibaca sulit untuk membaca pikiran pembaca kepada suasana lain atau imajinasinya.

\section{KAJIAN TEORI}

Puisi merupakan sebuah ungkapan perasaan yang ditulis melalui daya imajinatif seseorang melalui sebuah pengalaman hidup dengan menggunakan bahasa keindahan. 
Ada pendapat mengatakan bahwa puisi itu terlahir dari bawah sadar jiwa manusia. Tidak dapat dikuasai oleh logika, karena diciptakan secara spontan dan serta merta bersama emosi. Emosi yang lahir bersama irama. Menurut Waluyo (2002 :1) berpendapat karya sastra merupakan hasil cipta manusia yang dituangkan melalui kata-kata sehingga menjadi satu-kesatuan yang utuh. Jadi, puisi merupakan karya sastra, termasuk fiksi atau prosa. Pendapat ini memang ada benarnya , karena hal-hal yang bersifat puitis sebagai penanda puisi tidak hanya dapat ditemukan di dalam sajak, tetapi terdapat juga pada karya-karya lain. Selanjutnya, Menurut Kosasih (2012: 97) puisi yaitu sebuah ungkapan pikiran seseorang yang dituangkan dalam sebuah media dengan pemilihan kata-kata yang tepat dan bersifat keelokan. Keelokan puisi dikarenakan adanya kaidah penulisan puisi yang terkandung dalam karya sastra itu sendiri. Selanjutnya, Perrine (dalam Siswantoro 2010:23) karya sastra puisi yakni sebuah tulisan yang dapat di padu-padankan dengan kesatuan makna kata.

Oleh sebab itu, bahwa puisi merupakan sebuah tulisan yang dihasilkan pada sistem bahasa melalui keindahan dengan pemilihan kata, gaya bahasa, dan pola yang berirama secara secara imajinatif .

Bagian-bagian dari karya sastra yaitu bentuk tulisan yang memiliki kesan dan memiliki makna tertentu sebagai unsur pembangun dalam karya sastra itu sendiri. Bagianbagian tersebut menjelaskan bahwa terbentuknya karya sastra disebabkan dengan adanya bagian elemen lain sebagai pembangun karya sastra. Menurut Nurgiyantoro (2009: 23) bagian puisi terdapat dua komponen yakni bentuk fisik dan batin. Sejalan dengan pendapat Jabrohim (2001:33) mengungkapkan bahwa bagian puisi terdapat dari dua kelompok, yaitu: (1) bagian yang diperoleh dari fisik, bagian tersebut diantaranya adalah: pemilihan kata, daya imajinasi, bentuk realita, kata-kata indah, pola irama dan teknik memilih dan menyusun huruf sehingga menjadi tulisan yang baik. (2) bagian kedua disebut dengan komponen di mana komponen tersebut meliputi: topik, not, keadaan dan pesan. Unsur fisik suatu puisi meliputi beberapa hal. Berikut dipaparkan unsurusnur puisi yaitu sebagai berikut.

\section{1). Penggunaan Kata ( Pemilihan} Kata)

Biasanya seorang penulis puisi harus memperhatikan kata-kata yang digunakan dengan tepat, karena pemiliha kata dalam tulisan dapat digunakan untuk memberi makna sesuai dengan harapan yang penulis inginkan sehingga tercapailah tujuan dan keinginan penulis dalam berkarya. Oleh sebab itu, penulis harus banyak pengetahuan dalam hal kosa kata. Penggunaan kata-kata tersebut harus disesuaikan dengan makna kata, baik itu makna yang bersifat konotasi maupun denotasi dan lain sebagainya yang masih berkaitan dengan penulisan kata sehingga dapat berperan penting dalam penulisan puisi. Pemilihan diksi yang tepat akan menghasilkan keindahan bahasa. Karena dengan bahasalah seseorang akan mengetahui estetika. Kosa kata yang dituangkan dalam menciptakan puisi dalam medianya 
pada hakikatnya tidak berbeda dengan bahasa yang digunakan dalam kehidupan. Artinya, bahasa yang kita gunakan sama seperti bentuk bahasa lisan dan bahasa tulis. Hanya saja, bentuk penulisan puisi disampaikan secarat tersurat sedangkan bahasa lisan secara tersirat.

Namun, meskipun kata-kata tersebut dikatakan tidak berbeda bukan berarti kata yang diungkapkan sesuai dalam penulisan karya sastra puisi. Menurut Jauhari (2013:131). Pemilihan kata yang dituangkan dalam tulisan harus menggambarkan sebuah tempat, masa, pandangan, hasil, dan bunyi yang sesuai dengan karya yang diciptakan penulis. Menurut Tarigan (dalam Jauhari 2013:131). Sejalan dengan pendapat di atas, pemilihan kata yang tepat harus berkaitan dengan penggunaaan kosa kata yang bersifat kokerensi, di mana kata-kata tersebut memiliki kepaduan antar kata sehingga membentuk kalimat yang bermakna indah. (Sudjiman, dalam Hasanuddin 2002:99).

Oleh sebab itu, dikatakan bahwa diksi merupakan kata-kata yang penting dalam puisi kaya akan makna rimanya bersifat puitis dan merupakan salah satu bentuk satu-kesatuan yang utuh dan selaras.

Dalam sajak Sapardi Djoko Damono "Akulah Si Telaga"

Contoh:

Akulah si telaga: berlayar di atasnya;

Berlayarlah menyibakkan riak-riak kecil yang menggerakkan

Bunga-bunga pedma;

Berlayarlah sambil memandang harumnya cahaya;
Sesampai di seberang sana, tinggalkan saja -perahumu Biar aku yang menjaganya

(Sapardi Djoko Damono, perahu kertas:16 dalam, Hasanuddin 2002:102)

Sajak di atas, menggambarkan untuk menyatakan kerelaan melakukan pengorbanan kepada seseorang (orang tertentu), Sapardi berhasil memilih kata-kata tertentu yang kemudian membentuk perumpamaan. Pengorbanan itu disimbolkan bagai telaga yang menyediakan diri untuk dilayari . Tidak hanya sampai disitu, tetapi ternyata si telaga bersedia pula menjaga perahu yang telah dipergunakan seseorang (orang tertentu) untuk menyeberang telaga atau melayari telaga. Pemilihan kata yang membentuk perumpamaan tersebut membangkitkan gambaran angan (imajinasi) pembaca. Di samping itu, pemilihan kata pada sajak mestilah mempertimbangkan sisi lain. Bahasa di dalam sajak cenderung bahasa yang bermakna konotatif. Lewat pertimbangan semacam ini tentu pemilihan kata merupakan persoalan yang serius.

2). Citraan dalam Puisi

Citraan dalam puisi diartikan sebagai ungkapan kata-kata penulis yang bertujuan untuk mewujudkan perasaan si pembaca puisi atau pendengar dengan menghayati puisi tersebut sehingga dapat tersentuh dikarenakan dari sebuah ungkapan kata yang mendalam dari penulis seolah-olah pembaca ikut merasakannya. Daya pikir yang diungkapkan penyair seakan-akan membayangkan angan-angan atau menciptakan sebuah karangan dari proses 
pengalaman yang diperoleh dari hasil pengamatan yang dirasakan berdasarkan kenyataan bukan semata-mata diperoleh dari daya khayal penulis. Menurut Kosasih (2006:236) Citraan dalam puisi adalah proses sebuah angan-angan yang masih tersimpan melalui akal pikiran seseorang dan diperoleh berdasarkan dari hasil peristiwa kehidupan. Selanjutnya, Jauhari (2013:133) imaji artinya daya bayang. Daya bayang ini dibangun oleh pengalaman batin penulis karya sastra, khususnya puisi.

Oleh sebab itu, dapat dikatakan bahwa citraan dalam puisi merupakan pengungkapan sebuah kata-kata yang dituangkan melalui media yang diperoleh atas dasar peristiwa dan pengamatan oleh panca indra sehingga mampu untuk menyusun kosa kata melalui daya nalar sehingga mampu terciptanya sebuah karya sastra. Oleh sebab itu, bahwa pengimajinasian juga dapat dikatakan sebagai proses penyusunan kata serta pengungkapan dari sebuah peristiwa hidup dengan menggunakan bahasa yang bersifat puitis. Maka terciptalah perlakuan dalam proses pengimajinasian sehingga terbentuk sebuah puisi.

Dalam Puisi Chairil Anwar "Doa"

Contoh:

Kepada Pemeluk Teguh

Tuhanku

Dalam termangu

Aku masih menyebut nama-Mu

Biar susah sungguh

Mengingat kau penuh seluruh

Cahya-Mu panas suci

Tinggal kerdip lilin di kelam sunyi

Tuhanku

Aku hilang bentuk

Remuk

Tuhanku
Aku mengembara di negeri asing

Tuhanku

Dipintumu aku mengetuk

Aku tidak bisa berpaling

(Chairil Anwar dalam Jauhari, 2013:135)

Puisi di atas, menggambarkan seseorang yang sedang gundah dan termenung berdoa mengingat Tuhannya meminta tolong untuk menentramkan hatiya. Dia mengakui sedang mengembara di dunia, merasa banyak dosa, dan suatu waktu pasti kembali kepadaNya. Pada puisi yang berjudul doa terdapat tiga pengimajian atau pencitraan pada kalimat "Aku hilang bentuk remuk" terdapat pencitraan yaitu citraan perasa. "Di pintumu aku mengetuk" merupakan citraan pendengaran. "Aku tidak bisa berpaling" merupakan citraan perasa.

3). Kata Konkret

Kata konkret memiliki kata rujukan berupa sesuatu yang dapat diperoleh dari paca indra sehingga dapat diraskan, diraba, didengar, dan bisa dicium. Kata tersebut bersifat realistis artinya kata yang benar-benar terjadi dan nyata bisa dirasakan melalui indra seseorang. Untuk memahami lebih dalam tentang daya nalar pembaca, seharusnya kata tersebut perlu diungkapkan dengan keadaan yang nyata. Jikalau seorang penyair pandai dalam menyusun dan menggunakan kosa kata dengan secara realita, maka pembaca seakan-akan turut merasakan apa yang diungkapkan oleh seorang penyair. Oleh sebab itu, kata-kata yang bersifat realistis adalah kata yang memiliki wujud yang sesuai dengan keadaannya, sehingga pembaca dapat berimajinasi dengan bentuk kata serta 
perwujudannya yang dilukiskan oleh seorang penyair (Kosasih 2006: 236). Selanjutnya, menurut Waluyo (1987: 81) kata konkret adalah bentuk kata yang diperoleh dari hasil daya nalar yang memiliki bentuk realistis sehingga menjadi bagian dari proses berimajinasi. Maka, dengan istilah lain kata yang direalistiskan, pembaca dapat menggambarkan dengan keadaan yang sebenarnya secara pasti dari keadaan yang ungkapkan oleh penyair. Sependapat dengan Tarigan (2011: 33) kata nyata adalah kata yang semata-mata bersifat realitas, apa adanya dan bukan hayalan belaka. Oleh sebab itu, kata yang direalistiskan, seorang pembaca seakan-akan ikut merasakan keadaan yang digambarkan dengan jelas.

Dalam puisi "Gadis peminta-minta" Contoh:

Setiap kita bertemu, gadis kecil berkaleng kecil

Senyaummu terlalu kekal untuk kenal duka

Tengadah padaku, pada bulan merah jambu

Tapi kotaku jadi hilang, tanpa jiwa Ingin aku ikut, gadis kecil berkaleng kecil

Pulang kebawah jembatan yang melulur sosok

Hidup dari kehidupan angan-angan yang gemerlap

Gembira dari kemayaan riang

Duniamu yang lebih tinggi dari menara katedral

Melintas-luntas di atas air kotor, tapi yang begitu kau hafal

Jiwa begitu murni, terlalu murni

Untuk bisa membagi dukaku

Pada contoh puisi di atas menggambarkan seorang gadis yang hidupnya sangat memprihatinkan membutuhkan uluran tangan dari orang lain dengan membawa sebuah wadah kecil. Penyair menggunakan kata-kata gadis kecil berkaleng kecil. Ungkapan tersebut bersifat realistis karena menggambarkan sesosok gadis yang minimnya ekonomi untuk keperluan kebutuhan hidupnya. Ungkapan penyair tersebut menggambarkan seorang gadis yang miskin. Menggambarkan tempat berteduh yang pengap di bawah jembatan yang hanya dapat meluruskan tubuhnya, penyair menulis pulang kebawah jembatan yang melulur sosok. Untuk merealistiskanseorang pengemis yang hanya bersifat hayalan, penyair mengungkapkan hidup dari kehidupan angan-angan yang gemerlap gembira dari kemayaan riang. Untuk meralistiskan wujud penggambaran tentang harkat serta martabat seseorang yang artinya dunia gadis pengemis lebih rendah dibandingkan dengan kehidupan yang sesungguhnya, di mana lebih baik menjalankan kehidupan sebagaimana mestinya untuk menjalankan kebutuhan ekonomi.

\section{4). Bahasa Kiasan (Permajasan)}

Bahasa kiasan ialah bahasa yang digunakan penyair untuk mengungkapkan sesuatu dengan cara yang tidak biasa digunakan secara langsung dengan maknanya yang sesungguhnya. (Kosasih 2006: 237). Selanjutnya, Jauhari (2013: 136) majas adalah bahasa gambaran yang digunakan dengan bahasa-bahasa yang tidak langsung diungkpan oleh penyair. Oleh sebab itu, bahasa yang digunakan adalah termasuk dalam makna yang bersifat tidak sebenarnya. Makna tersebut hanya 
berbentuk kiasan secara tersirat seolah-olah hanya terkesan estetik dan bermakna lugas. Majas digunakan penyair untuk menyampaikan perasaan, pengalaman batin, harapan, suasana hati, ataupun semangat hidup. Hal ini dilakukan agar penyair terhindar dari keterbatasan kata-kata denotatif yang bermakna lugas.

Hal ini terkadang memerlukan perhatian khusus untuk menangkap pesan dari pengarang. Penggunaan bentuk-bentuk kiasan dalam kesastraan, dengan demikian merupakan salah satu bentuk penyimpangan kebahasaan, yaitu penyimpangan makna. Untuk menggambarkan keadaan ombak, penyair menggunakan majas personifikasi berikut.

Contoh:

Risik risau ombak memecah

Di pantai landai

Buih berderai

(dalam Kosasih 2012 :104)

Berdasarkan kutipan di atas, ombak diibaratkan seperti makhluk hidup yang dapat bergerak dan merasakan suasana keadaan. Disisi lain bahwa permajasan dapat mempengaruhi gaya bahasa sehingga dapat mewujudkan keindahan pada bahasa. Perhatikan misalnya, untaian kata-kata Di pantai landai/buih berderai. Kata tersebut itu tampak estetik (puitis) dengan menggunakan rima yang berbunyi /a/ dan /i.

\section{5). Irama}

Menurut Kosasih (2006: 239) irama ialah reduplikasi sebuah fonem yang dituliskan dalam karya sastra puisi. Irama berguna untuk menghasilkan sebuah bunyi pada nada suara. Oleh sebab itu, dengan diiringi sebuah irama pada puisi, maka bunyi yang diucapkan baik oleh penyair maupun pembaca akan menimbulkan bunyi nada yang terkesan indah dan memiliki makna tersendiri apabila si pembaca membawakan dengan penuh penghayatan. Irama juga disebut sebagai ritma, di mana terdapat sebuah reduplikasi dalam larik-larik puisi. Selanjutnya, menurut Jauhari (2013: 139) Irama ialah sebuah reduplikasi bunyi yang pengulangannya masih sama. Irama merupakan bagian terpenting dari sebuah puisi. Oleh sebab itu, irama menjadi salah satu dasar yang harus diapresiasikan dalam karya sastra puisi, sehingga dapat membangun terbentuknya puisi yang memiliki aspek keindahan pada bunyi-bunyi fonem tersebut. Sedangkan ritme ialah tinggi, rendahnya suara pada sebuah intonasi dalam pembacaan puisi. Oleh sebab itu, bahwa irama dan ritme pada puisi, sangat berkaitan erat. Di mana keduanya tidak bisa terpisahkan, karena bagian aspek tersebut salah satu dasar pembangun karya sastra puisi.

6). Tata Wajah

Tipografi merupakan suatu keindahan sebuah seni dalam memilih dan menyusun rentetan huruf pada bagian yang akan ditulis guna menciptakan kesan yang mendalam sehingga para pembaca mendapatkan kenyamanan dan merasa terlibat dalam teks penyair. Oleh sebab itu, fungsi utama dari tipografi adalah agar para pembaca lebih mudah dalam memahami isi teks dan pilihan kata yang digunakan memiliki kesan bahasa yang 
menarik sehingga menumbuhkan rasa penasaran yang tinggi untuk dibaca.

\section{1).Topik dan Pesan}

Topik dan pesan adalah sebuah elemen pembangun karya sastra, karena keduanya saling berkaitan erat yang dapat mengembangkan sebuah karya sastra itu sendiri. Maka dapat dijelaskan bahwa topik merupakan sebuah ide atau pokok pikiran seseorang yang akan diungkapkan melalui tulisan yang jumlahnya tidak terbatas. Sedangkan pesan yaitu ungkapan penulis dalam sebuah cerita yang terkandung nilai-nilai moral maupun dalam bentuk nasehat dengan tujuan pengarang ingin menggambarkan sebuah pesan secara tersurat atau tersirat pada karya sastra yang diciptakan.

\section{2). Keadaan Batin}

Keadaan batin adalah ungkapan perasaan dan pikiran pengarang tentang hidup yang dialaminya. Di dalam karya sastra pengarang menciptakan berbagai suasana yang dapat menimbulkan ekspresi jiwa seseorang yang diungkapkan oleh pengarang. Biasanya keadaan tersebut akan dirasakan oleh pembaca apabila teks dalam puisi benar-benar dibaca dengan penuh penghayatan sehingga dengan sendirinya ikut merasakan hal yang diungkapkan melalui ekspresi mimik dan bahasa tubuh.

\section{3). Bunyi dan Keadaan}

Bunyi atau nada yaitu suara yang menggunakan aturan, yakni memiliki frekuensi tunggal tertentu. Dalam teori musik, setiap bunyi memiliki tinggi nada tertentu. Menurut frekuensinya ataupun menurut jarak relatif bunyi tinggi nada tersebut terhadap tinggi nada patokan. Bunyi dapat diatur dalam tangga nada yang berbeda-beda. Sedangkan suasana yaitu keadaan penyair dalam menciptakan karya sastra. Keadaan yang diperoleh dari sebuah karya penyair yang dapat diungkapkan dalam tulisan atau atas dasar pengalaman hidup. Oleh sebab itu, bunyi dan suasana puisi saling berkaitan erat karena nada puisi dapat menunjukan keadaan hati yang sesungguhnya sehingga dapat diapresikan melalui karya sastra.

Adapun definisi yang dirumuskan untuk menjelaskan perihal puisi, selalu saja definisi tersebut dinilai kurang tepat dan tidak memuaskan. Akibatnya, bermunculan lagi definisi-definisi lain. Oleh karena itu, untuk lebih memahami tentang puisi diperlukan uraian tentang jenisjenis puisi. Seperti karya sastra lainnya puisi juga memiliki jenisjenis. Menurut Kosasih (2006: 242). Pada hakikatnya penyair karya sastra dapat mengelompokkan puisi ke dalam tiga bagian yaitu : puisi narasi, puisi irama, puisi penggambaran.

\section{1). Puisi Narasi}

Puisi narasi merupakan sebuah karya dalam bentuk larik-larik di mana larik tersebut menceritakan tentang pembuat puisi itu sendiri atau penyair. Menurut Kosasih (2006: 242) Puisi narasi adalah ungkapan pengarang yang dituangkan dengan menggunakan penggambaran dalam bentuk teks secara luas. Bagian karya sastra puisi dapat di kelompokkan menjadi tiga jenis yaitu: 
a. Balada yaitu sajak sederhana yang mengisahkan cerita rakyat yang mengharukan, kadangkadang dinyanyikan, kadangkadang berupa percakapan.

b. Epigram yaitu karya sastra berisi tentang unsur pengajaran, pernyataan singkat, nasehat yang baik dan terkadang pernyataan tersebut dapat mengejutkan.

c. Romance yaitu puisi yang berisi tentang kisah kehidupan yang menjalin hubungan asmara/cinta hingga mencapai kehidupan yang bahagia.

2). Puisi lirik

Puisi lirik merupakan puisi yang menceritakan tentang suasana hati penyair yang dituangkan kedalam tulisan. Menurut Kosasih (2006: 242) puisi lirik yaitu puisi yang mengandung curahan rasa dan suasana hati bagai luapan batin pengarang.

Puisi ini terbagi ke dalam beberapa macam:

a. Elegi merupakan kesusateraan si penyair yang pengungkapannya merujuk pada suasana kesedihan.

b. Ode merupakan puisi yang tatanannya memuji atau memuliakan suatu kejadian atau individu, melukiskan suasana alam secara intelektual dan juga emosional.

c. Serenada merupakan alunan musik yang dinyanyikan pada waktu senja dengan tujuan penghormatan.

3). Puisi Penggambaran

Puisi penggambaran adalah puisi yang berisi tentang pengalaman atau peristiwa yang terjadi. Menurut Kosasih (2006: 243) puisi penggambaran merupakan puisi yang di dalamnya melukiskan objek tertentu, baik melukiskan sebuah kisah, suasana alam, keadaan tempat dan sebagainya. Misalnya satire, puisi yang bersifat social atau impresionistik.

Di Indonesia puisi dapat dikelompokkan menjadi dua bagian yaitu puisi tradisional dan puisi modern. Menurut Pradopo, dkk (2001: 2.3) puisi tradisional disebut sebagai puisi Melayu Klasik. Sesuai dengan masyarakat lama puisi Melayu Klasik ini mengungkapkan bahasa eksperesif, suasana, pendapat dan perasaan. Puisi tradisional terbagi menjadi beberapa bagian, yakni: mantra, seloka, gurindam, pantun, dan syair.

Pada dasarnya sebuah citraan atau pengimajian masih berkaitan erat dengan pemilihan kata. Artinya pemilihan kata yang tepat akan menyebabkan daya nalar terhadap sesuatu. Daya nalar atau imajinasi akan tersentuh oleh pembaca karena semakin tinggi bahasa pengimajinasian yang diungkapkan pengarang akan tergambarkan secara langsung melalui alat indra. Citraan dapat terbagi dari berbagai macam jenisnya (Hasanuddin, 2002: 177). Berikut diuraikan jenis citraan yang sering digunakan penyair untuk membangun sarana kepuitisan.

1). Citraan Penglihatan (Visual Imagery)

Citraan penglihatan dapat diartikan sebagai reproduksi mental, suatu ingatan masa lalu yang bersifat inderawi yang diformulasikan ke dalam rangkaian kata yang bersifat simbiolis. Jadi, citra penglihatan dapat dipahami sebagai ciri penglihatan yang memberi rangsangan kepada indra penglihatan sehingga sering hal-hal 
yang tidak terlihat menjadi seolaholah terlihat.

\section{2). Citraan Pendengaran ( Auditory} Imagery)

Citraan pendengaran adalah citraan yang timbul oleh pendengaran. Citraan pendengaran merupakan pelukisan bahasa yang merupakan perwujudan dari pengalaman pendengaran. Berbagai peristiwa dan pengalaman hidup yang berkaitan dengan pendengaran tersimpan dalam memori pembaca akan mudah bangkit dengan adanya citraan audio atau pendengaran. Citraan pendengaran akan merangsang indra pendengaran sehingga, halhal yang semula tidak terlihat akan tampak di depan pembaca dengan rangsangan-rangsangan pendengaran.

3). Citraan Penciuman (Smell imagery)

Citraan penciuman jarang digunakan oleh penulis, namun citraan penciuman memiliki fungsi penting dalam menghidupkan imaji pembaca. Citraan penciuman adalah penggambaran yang diperoleh melalui pengalaman indra penciuman. Citraan jenis ini dapat membangkitkan emosi penciuman pembaca untuk memperoleh gambaran yang lebih utuh atas pengalaman indra yang lain.

4). Citraan Pengecapan atau Rasaan (Taste Imagery)

Citraan pengecap adalah pelukisan imajinasi yang ditimbulkan oleh pengalaman indra pengecap. Citraan ini dalam karya sastra dipergunakan untuk menghidupkan imaji pembaca dalam hal-hal yang berkaitan dengan rasa di lidah.

5). Citraan perabaan (Tactile Imagery)

Citraan rabaan adalah penggambaran sebuah cerita yang diperoleh melalui pengalaman indra perabaan. Citraan perabaan sering menggambarkan sesuatu yang erotik dan sensual sehingga dapat memancing imajinasi pembaca.

6). Citraan Gerak (Kinaesthetic Imagery)

Citraan gerak adalah citraan yang melukiskan sesuatu yang sesungguhnya tidak bergerak tetapi dilukiskan sebagai benda yang dapat bergerak ataupun gambaran gerak pada umumnya. Citraan gerak dapat membuat sesuatu menjadi terasa hidup dan terasa menjadi dinamis.

Bentuk karya sastra tidak mutlak secara harfiah. Akan tetapi, bentuk pencitraan yang muncul dalam karya sastra dapat juga bersifat kiasan, misalnya yang berupa perbandingan-perbandingan.

Dengan demikian, bentuk atau gaya pencitraan dapat muncul sekaligus lewat kalimat dengan gaya pemajasan, dan keduanya pun dapat bergabung dalam satu kalimat dengan gaya penyiasatan struktur.

Pengimajinasian dapat diartikan sebagai kata-kata diksi yang memengaruhi pengarang melalui daya nalar yang diungkapkan dengan bahasa yang indah.

Menurut Kosasih (2006:236) pengimajian merupakan rentetan kata-kata yang diungkpan pengarang dengan gaya bahasa yang puitis. Selanjutnya, Jauhari (2013:133) imaji artinya daya 
bayang. Daya bayang ini dibangun oleh pengalaman batin penulis karya sastra, khususnya puisi.

Oleh sebab itu, bahwa pengimajian merupakan rentetan beberapa kata secara terstuktur dengan menggambarkan peristiwa melalui daya imajinasi pengarang yang diperoleh dari panca indra.

\section{Dalam Puisi Chairil Anwar "Doa"}

Contoh:

Kepada Pemeluk Teguh

Tuhanku

Dalam termangu

Aku masih menyebut nama-Mu

Biar susah sungguh

Mengingat kau penuh seluruh

Cahya-Mu panas suci

Tinggal kerdip lilin di kelam sunyi

Tuhanku

Aku hilang bentuk

Remuk

Tuhanku

Aku mengembara di negeri asing

Tuhanku

Dipintumu aku mengetuk

Aku tidak bisa berpaling

(Chairil Anwar dalam Jauhari, 2013:135)

Puisi di atas, menggambarkan seseorang yang sedang gundah dan termenung berdoa mengingat Tuhannya meminta tolong untuk menentramkan hatinya. Dia mengakui sedang mengembara di dunia, merasa banyak dosa, dan suatu waktu pasti kembali kepadaNya. Pada puisi yang berjudul doa terdapat tiga pengimajian atau pencitraan pada kalimat "Aku hilang bentuk remuk" terdapat pencitraan yaitu citraan perasa. " Di pintumu aku mengetuk"merupakan citraan pendengaran. "Aku tidak bisa berpaling" merupakan citraan perasa.
Puisi merupakan bagian unsur terpenting dari karya sastra. Di dalam puisi seorang pengarang dapat menggambarkan berbagai ungkapan dengan menggunakan kata-kata kiasan, selain itu juga terdapat penggunaan gaya bahasa. Oleh sebab itu, dengan keindahan bahasa yang digunakan pengarang, sehingga dapat menggugah para pembaca untuk menikmati sastra. Puisi dapat diciptakan dan dibangun secara utuh karena disebabkan dari beberap hal oleh pemilihan kata, gaya bahasa, irama, dan lirik yang tertuang dalam karya sastra tersebut. Kekayaan makna yang dapat dituangkan dalam bentuk tulisan. Ada pendapat mengatakan bahwa puisi itu terlahir dari bawah sadar jiwa manusia. Tidak dapat dikuasai oleh logika, karena diciptakan secara spontan dan serta merta bersama emosi. Emosi yang lahir bersama irama. Menurut Kosasih (2012:97) puisi merupakan sebuah karya sastra yang indah. Selanjutnya, Perrine (dalam Siswantoro 2010:23) puisi adalah hasil karya cipta manusia yang dituangkan dengan bahasa yang utuh. Sejalan dengan pendapat di atas, Kosasih (2006:247) puisi adalah sebuah kesusasteraan lama yang harus dikembangkan oleh pecinta sastra. Dengan demikian, bahwa menulis puisi adalah usaha seseorang untuk menuangkan gagasan, perasaan, dan imajinasinya ke dalam puisi dengan bahasa yang indah dan menarik serta sarat dengan makna dan nilai kehidupan khususnya bagi pembaca.

Berikut langkah-langkah dalam menulis puisi sebagai berikut.

a). Menentukan Topik 
Topik merupakan bagian dari isi puisi. Topik adalah pokok pikiran yang ada dalam puisi sebagai salah satu unsur untuk mengembangkan karya sastra menjadi sebuah satukesatuan yang utuh. Oleh sebab itu, topik merupakan unsur pembangun dalam karya sastra. Sehingga karya sastra tersebut dapat dikembangkan dengan baik oleh penyair. Dalam menentukan topik pengarang harus mengetahui terlebih dahulu.cTopik yang ditentukan pastinya pengarang mengetahui dari hasil peristiwa atau pengamatan langsung dari panca indra. Sehingga pengarang mudah dalam menuangkan ide atau gagasan tersebut. Topik yang sering dipakai dalam menulis puisi bersifat bebas. Artinya tidak terikat dengan situasi tertentu karena berdasarkan objek pengamatan.

\section{b). Pemilihan Kata}

Menulis puisi pastinya harus menggunakan kata-kata yang mudah dipahami oleh pembaca. Penggunaan kata yang tepat dalam puisi dengan untaian kata-kata puitis, dan penggunaan gaya bahasa yang menarik. Maka, pembaca akan semakin penasaran untuk mengetahui arti makna puisi tersebut. Kata-kata yang dituangkan dalam puisi biasanya bermakna sebenarnya atau lugas. Oleh sebab itu, bergantung pembaca dalam memaknainya.

c). Pemilihan Majas

Dalam menulis puisi pengarang mengungkapkan sebuah perasaan melalui ngkapan bahasa yang disampaikan agar puisi terkesan memiliki nilai estetika. Puisi yang dibuat tanpa menggunakan majas terkesan hanya sebatas kata-kata biasa yang sulit membuat pembaca terhanyut.

d). Kemampuan Memiliki Imajinasi Kemampuan krativitas tidak terlepas dari daya nalar seorang pengarang. Kemampuan yang memiliki daya nalar yang tinggi, maka seseorang akan mudah dalam mengapresiasikan karya sastra dalam bentuk tulisan. Karena, imajinasi diperoleh dari pusat konsentrasi dan berdasarkan pengetahuan imajinya.

Menurut Kosasih (2006: 247) mengungkapkan bahwa langkahlangkah dalam menulis puisi adalah sebagai berikut :

1. Puisi diperoleh dari ungkapan perasaan serta keadaan pengarang melalui psikologisnya secara otodidak dengan bahasa yang komunikatif. Artinya semata-mata tidak berdasarkan dari pengalaman hidup. Pengarang menggunakan bahasa-bahasa ekspresif dalam pengungkapannya, sehingga puisi tidak terkesan monoton.

2. Pengarang handaknya memberikan arti pentingnya dalam melatih ketrampilan menulis karya sastra terhadap pembaca sebagai dasar kesadaran diri. Topik yang kita tulis berdasarkan inspirasi dari seseorang yang akan menciptakan karya sastra.

3. Pengungkapan sebuah ide atau gagasan diperoleh dari daya nalar pengarang untuk disampaikan dalam bentuk tulisan dengan menggunakan pemilihan kata dan gaya bahasa yang sesuai.

Berikut pengertian dari gaya bahasa yaitu :

a). Gaya bahasa merupakan struktur kata yang muncul dari 
pokok pikiran seorang penyair dan diungkapan melalui bahasa kiasan. b). Gaya bahasa merupakan untaian beberapa kata sebagai unsur estetika dalam puisi sehingga puisi akan menjadi lebih menarik untuk dibaca.

Menulis puisi merupakan kegiatan yang sangat menyenangkan karena seseorang dapat leluasa menuangkan isi yang ada dalam pikiran secara bebas.

\section{METODE}

Metode penelitian yang penulis gunakan yakni deskriptif kualitatif. Penggunaan metode ini dimaksudkan untuk mendeskripsikan kemampuan siswa kelas VIII Semester genap SMP Perintis 2 Bandar Lampung Tahun Pelajaran 2019/2020 dalam menulis puisi secara objektif diuraikan dalam bentuk deskripsi kata-kata sebab data berupa hasil karya tulis, yakni puisi.

Teknik analisis metode yang digunakan dalam penelitian ini adalah teknik deskripitif kualitatif. Maksudnya, mendeskripsikan puisi siswa berdasarkan unsur-unsur puisi dan menguraikan dengan serangkaian kata-kata yang ada dalam tiap larik puisi. Metode yang dilakukan berpedoman kepada pendapat Rafiek (2013:4) mengemukakan bahwa analisis dapat dilakukan dengan cara sebagai berikut:

1). Bacalah karya sastra yang hendak dikaji terlebih dahulu sampai anda menguasai betul isi karya sastra tersebut.

2). Bacalah dan kuasai teori sastra dari yang tradisional sampai mutakhir sehingga anda tidak ketinggalan dengan perkembangan teori sastra.
3). Bacalah dan kuasai metode penelitian sastra karena dengan metode yang tepat dan benar suatu karya sastra akan dapat dikaji dengan baik.

4). Mulailah mengkaji karya sastra dengan terlebih dahulu mencari dan menemukan data yang akan dikaji dalam karya sastra.

5). Memulai menganalisis dan membahas karya sastra dengan menggunakan bahasa anda sendiri dilengkapi dengan panduan teori sastra yang kuat.

6). Mengkaji dan terus mengkaji karya sastra sehingga kajian sastra anda mendalam dan lengkap.

7). Segera lakukan perbaikan secara menyeluruh jika terdapat kekeliruan dalam mengkaji karya sastra setelah mendapat saran dan komentar dari teman yang mengerti sastra dan ahli sastra.

8). Setelah selesai melakukan pengkajian sastra, lakukan diskusi sastra kecil-kecilan dengan temanteman di kelas atau di kampus.

Berdasarkan teori tersebut, maka sebagai langkah penyesuaian analisis kemampuan menulis puisi siswa, dilakukan berbagai cara sebagai berikut:

1). Melafalkan puisi yang ditulis oleh peserta didik.

2).Mengidentifikasi atau menemukan ketidaktepatan puisi siswa dengan aspek yang dikaji.

3). Menganalisis kesalahan dan membahasnya.

4). Mengecek kembali analisis yang telah dilakukan.

5). Menyimpulkan.

\section{HASIL DAN PEMBAHASAN}

Pembahasan temuan penelitian, terkait dengan kemampuan siswa kelas VIII semester genap SMP Perintis 2 Bandar Lampung Tahun 
Pelajaran

2019/2020,

dikemukakan sebagai berikut.

1). Terkait dengan pertanyaan penelitian, khususnya tentang tingkat kemampuan menulis puisi siswa kelas VIII Semester genap SMP Perintis 2 Bandar Lampung Tahun Pelajaran 2019/2020, dapat dikemukakan bahwa kemampuan siswa dalam menulis puisi belum sepenuhnya dapat dikatakan berhasil sebab dari beberapa aspek yang harus diperhatikan dalam menulis puisi, umumnya belum secara maksimal muncul atau diterapkan dalam puisi siswa. Kesalahan atau kelemahan siswa yang sering dilakukan yaitu pada aspek rima, diksi, dan kata konkret. Rata-rata setiap siswa dalam menulis puisi kurang tepat atau tidak menggunakan aspek tersebut. Puisi yang ditulis siswa terkesan seperti prosa, mereka menggunakan kata-kata yang datar dan biasa, sehingga puisi yang ditulis kurang memberikan nilai keindahan. Tidak adanya rima pada tiap baitnya dalam puisi yang ditulis siswa juga merupakan salah satu kelemahan siswa, rima yang mereka buat cenderung acakacakan, sehingga rima pada puisi tidak jelas dan menimbulkan ketidakselarasan bunyi pada puisi. Bahkan, puisi yang ditulis, cenderung kurang dapat memanfaatkan majas atau gaya bahasa-gaya bahasa yang menarik.

2). Pertanyaan penelitian tentang faktor penyebab kesulitan siswa kelas VIII Semester genap SMP Perintis 2 Bandar Lampung Tahun Pelajaran 2019/2020 dalam menulis puisi, dapat dipaparkan bahwa terdapat kecenderungan siswa masih belum maksimal menulis puisi karena beberapa aspek, yaitu: 1) Ketidakpapahaman siswa terhadap konsep puisi secara umum dan khusus. Ketidakpahaman siswa terhadap konsep puisi secara umum yakni siswa sering salah membedakan puisi dengan prosa. Ada sebagian siswa yang menyatakan bahwa puisi itu dapat dikatakan prosa, padahal konsep keduanya berbeda. Prosa lebih bebas dalam tatanan bahasanya, sedangkan puisi sangat terikat dengan norma puisi. 2) Kurangnya intensitas siswa dalam menulis puisi menyebabkan puisi yang ditulis seperti tidak tersusun dengan baik. Proses menulis puisi yang terus-menerus sangat berdampak positif atas keberhasilan peserta didik dalam membuat puisi karena terbiasa mengungkapkan ide atau gagasan dalam bentuk puisi. 3) Beberapa peserta didik berasumsi bahwa membuat puisi itu sukar karena harus indah, padahal menulis puisi itu mudah jika dilakukan dengan terus menerus dan norma-norma puisi selalu diaplikasikan dengan baik dan konsisten. 4) Siswa terlihat tidak cukup memiliki perbendaharaan kata sehingga puisi yang ditulis terkesan menggunakan kata-kata yang monoton dan tidak bervariatif. Kurangnya perbendarahaan kata dimiliki oleh siswa disebabkan oleh enggannya siswa membaca atau menghafal kata-kata dalam buku pedoman bahasa. 5) Faktor terakhir yang berhasil diidentifikasi yakni berkenaan dengan imajinasi. Menulis puisi sudah pasti bersumber dari imajinasi, namun imajinasi yang muncul dalam puisi siswa terkesan kurang menentuh perasaan pembaca terutama saat 
puisi siswa dianalisis. Hal tersebut disebabkan oleh ide atau gagasan dalam diri siswa sepertinya terbatas kepada hal-hal yang diketahui siswa saja. Padahal, ide, gagasan, dan imajinasi siswa dapat berkembang dengan sendirinya ketika melihat sesuatu.

3). Pertanyaan terakhir dari penelitian ini yakni terkait dengan langkah mengatasi kesulitan siswa kelas VIII Semester genap SMP Perintis 2 Bandar Lampung Tahun Pelajaran 2019/2020 dalam menulis puisi. Jika bertolak dari faktor-faktor kesulitan siswa dalam membuat puisi, berikut diuraikan penjabarannya yaitu:

Pengetahuan peserta didik yang kurang tentang konsep menulis puisi, dapat disiasati dengan memberikan rujukan yang baik kepada siswa sehingga dapat dipelajari, dibaca, dan dipahami dengan baik. Rujukan atau referensi yang diberikan dapat dibawa pulang sehingga siswa dapat mempelajari konsep-konsep menulis puisi setiap saat. Hal yang harus diperhatikan bahwa siswa perlu diberi tugas jika referensi diberikan kepada siswa dan dipelajari di rumah. Artinya, ada tindak lanjut dari proses yang laksanakan oleh peserta didik baik di lingkungan pendidikan maupun di lingkungan keluarga. 2) Jika sebelumnya intensitas siswa dalam menulis puisi dinilai kurang atau proses berlatih cenderung jarang dilakukan, maka hal tersebut dapat disiasati dengan memberikan tanggung jawab kepada siswa tentang perlunya menulis puisi sebagai bentuk kreatifitas diri. Maksudnya, siswa dapat melakukan tugas menulis puisi setiap harinya meski tidak dalam mata pelajaran bahasa Indonesia. Prosesnya dapat dilakukan di luar jam sekolah bahkan dapat dilakukan di rumah dengan minta pengawasan orang tua.

Cara ini dinilai akan menimbulkan kemauan yang keras dalam diri siswa untuk menulis puisi. 3) Jika siswa sudah melakukan proses berlatih yang cukup, baik di lingkungan pendidikan maupun di lingkungan keluarga, hal ini akan membuat asumsi peserta didik dalam menulis puisi itu sulit. Artinya, jika siswa terbiasa menulis puisi, maka kesulitan yang menjadi alasan akan hilang dengan sendirinya. Motivasi siswa akan kembali normal atau lebih memiliki semangat yang tinggi untuk menulis puisi. 4) Selain hal di atas, siswa juga beranggapan bahwa sulit merangkai kata-kata dalam menulis puisi. Kondisi tersebut disebabkan oleh minimnya perbendaharaan kata yang dimilik oleh siswa dan tidak menguasai masalah atau materi yang akan diulas dalam puisi. Perbendaharan kata siswa akan bertambah jika selalu dapat menemukan dan mengamalkan kata-kata dalam kamus bahasa Indonesia, baik dalam aktivitas berbahasa lisan terlebih tulisan.

\section{SIMPULAN}

Dari hasil pembahasan metode yang telah dilaksanakan, maka dapat ditarik kesimpulan bahwa kemampuan siswa kelas VIII semester genap SMP Perintis 2 Bandar Lampung Tahun Pelajaran 2019/2020, dalam menulis puisi belum sepenuhnya dapat dikatakan berhasil. Hal ini berdasarkan masih adanya sebagian unsur-unsur yang tidak dapat diungkapkan atau kurang 
tepat dalam puisi siswa. Kesalahan atau kelemahan siswa yang sering dilakukan yaitu pada aspek rima, diksi, dan kata konkret. Rata-rata setiap siswa dalam menulis puisi kurang tepat atau tidak menggunakan aspek tersebut. Puisi yang ditulis siswa terkesan seperti prosa, mereka menggunakan katakata yang datar dan biasa, sehingga puisi yang ditulis kurang memberikan nilai keindahan. Tidak adanya rima pada tiap baitnya dalam puisi yang ditulis siswa juga merupakan salah satu kelemahan siswa, rima yang mereka buat cenderung tidak berpola sesuai struktur bunyinya, sehingga rima pada puisi tidak jelas dan menimbulkan ketidakselarasan bunyi pada puisi.

Berikut simpulan penelitian dari pertanyaan penelitian yang diajukan:

1). Kemampuan menulis puisi siswa kelas VIII Semester genap SMP Perintis 2 Bandar Lampung Tahun Pelajaran 2019/2020, belum sepenuhnya dapat dikatakan berhasil sebab dari beberapa aspek yang harus diperhatikan dalam menulis puisi, umumnya belum secara maksimal muncul atau diterapkan dalam puisi siswa. Kesalahan atau kelemahan siswa yang sering dilakukan yaitu pada aspek rima, diksi, dan kata konkret. Setiap siswa dalam menulis puisi kurang tepat atau tidak menggunakan aspek tersebut. Puisi yang ditulis siswa terkesan seperti prosa, mereka menggunakan kata-kata yang datar dan biasa, sehingga puisi yang ditulis kurang memberikan nilai keindahan. Tidak adanya rima pada tiap baitnya dalam puisi yang ditulis siswa juga merupakan salah satu kelemahan siswa, rima yang mereka buat cenderung acak-acakan, sehingga rima pada puisi tidak jelas dan menimbulkan ketidakselarasan bunyi pada puisi. Bahkan, puisi yang ditulis, kurang dapat memanfaatkan majas atau gaya bahasa yang menarik.

2). Faktor penyebab kesulitan siswa kelas VIII Semester genap SMP Perintis 2 Bandar Lampung Tahun Pelajaran 2019/2020 dalam menulis puisi, yakni siswa masih belum maksimal menulis puisi karena disebabkan oleh beberapa faktor, yakni

Ketidakpapahaman siswa terhadap konsep puisi secara umum dan khusus. 2) Kurangnya intensitas siswa dalam menulis puisi menyebabkan puisi yang ditulis seperti tidak tersusun dengan baik. 3) Beberapa siswa menganggap bahwa menulis puisi itu sulit karena harus indah, padahal menulis puisi itu mudah jika dilakukan dengan terus menerus dan norma-norma puisi selalu diaplikasikan dengan baik dan konsisten, 4) Siswa terlihat tidak cukup memiliki perbendaharaan kata sehingga puisi yang ditulis terkesan menggunakan kata-kata yang monoton dan tidak bervariatif, 5) Imajinasi yang muncul dalam puisi siswa terkesan kurang menyentuh perasaan pembaca terutama yang terdapat pada puisi siswa yang dianalisis. Padahal, ide, gagasan, dan imajinasi siswa dapat berkembang dengan sendirinya ketika melihat sesuatu.

3). Langkah mengatasi kesulitan siswa kelas VIII Semester genap SMP Perintis 2 Bandar Lampung Tahun Pelajaran 2019/2020 dalam menulis puisi, yakni memberikan 
rujukan yang baik kepada siswa sehingga dapat dipelajari, dibaca, dan dipahami dengan baik dan melakukan tindak lanjut dari proses yang dilakukan oleh siswa. Siswa harus berlatih menulis puisi secara lebih intensif sehingga terbiasa dengan menulis puisi. Hal tersebut akan menghilangkan dalam benak siswa bahwa menulis puisi itu sulit. Siswa membaca kamus-kamus sastra dan kamus bahasa Indonesia untuk memperkaya perbendaharan kata dan dapat digunakan dalam menulis puisi sehingga membentuk kata yang bervariatif.

\section{DAFTAR PUSTAKA}

[1] Burhan, Nurgiyantoro. (2009). Penilaian Pengajaran Bahasa. Yogyakarta: BPFE.

[2] Anwar Chairil. (2013). Teori dan Apresiasi Puisi. Jakarta: PT Gunung Agung.

[3] Dalman. (2012). Keterampilan Menulis. Jakarta: PT Raja Grafindo Persada.

[4] Jauhari, Heri. (2013). Terampil Mengarang. Bandung: Nuansa Cendekia.

[5] Jabrohim(2001). Kajian Sastra: Teori dan Kritik Pada Karya Sastra. Sunda Indonesia. Bandung: Daluang Publishing.

[6] Kosasih, E. (2006). Kompetensi Ketatabahasaan dan Kesusasteraan. Bandung: Kiblat Buku Utama.

[7] Kosasih, E. (2012). Dasar-dasar Ketrampilan Bersastra. Bandung: Yrama Widya.
[8] Pradopo, Rachmat Djoko. (2012). Pengkajian Puisi. Yogyakarta: Gadjah Mada University Press

[9] Rafiek,M. (2013). Pengkajian Sastra. Bandung: PT Refika Aditama.

[10] Siswantoro. (2010). Metode Penelitian Sastra. Yogyakarta: Penerbit Pustaka Pelajar.

[11] Tarigan, Hendry Guntur. (2011). Berbicara Sebagai Suatu Keterampilan Berbahasa. Bandung: Rosdakarya.

[12] Tarigan, Hendry Guntur. (2013). Prinsi- Prinsip Dasar Sastra. Bandung: Angkasa Bandung.

[13] Waluyo, J Herman. (1987). Teori dan Apresiasi Puisi. Jakarta: Erlangga.

[14] Waluyo, J Herman. (2002). Apresiasi Puisi. Jakarta: Gramedia Pustaka Utama.

[15] Ws, Hasanuddin. ( 2002). Membaca dan Menilai Sajak. Bandung: Angkasa Bandung. 